\title{
Urban Morphology: The Classical and Modern Research Methodologies
}

\author{
Ágnes Bertyák ${ }^{1 *}$ \\ ${ }^{1}$ Department of Urban Planning and Design, Faculty of Architecture, Budapest University of Technology and Economics, \\ H-1111 Budapest, Múegyetem rakpart 3, Hungary \\ * Corresponding author, e-mail: bertyak.agnes@gmail.com
}

Received: 07 February 2021, Accepted: 09 November 2021, Published online: 21 December 2021

\begin{abstract}
This article aims to explore the Hungarian and foreign urban morphological studies as a basis for possible new investigation methods that can follow or innovate the existing methodologies. For this reason, the exploration of the currently known models is essential. The "classical" morphological studies dealt with the structural shapes, historical elements, and changes of the settlements, based mainly on empirical and manual research. In the 1980s, new "modern" research methods emerged with the help of computer software, statistical data and Geographical Information Systems, representing a quantitative approach. Today inter- and multidisciplinary morphological studies are also widespread, combining several areas like ecology, sociology or sustainability with urban studies providing new research directions.
\end{abstract}

Keywords

classical or traditional urban morphology, modern or contemporary urban morphology, systematisation, development

\section{Introduction}

The concept of urban morphology is widely known and applied in several disciplines; however, precisely for this reason, its interpretation and framework vary greatly. Although the different fields of study examine the same topic, the settlement and the elements and changes of its forms and structures, they endow it with different meanings and readings. Thus, urban morphology can also be the field of societal research and its spatial connections, the appearance and relationship of certain landscape, geographical, ecological and built elements, or even the presence and impact of tourism. This review study aims to systematise the different theoretical backgrounds, methods, and tools of urban morphology studies both internationally and in Hungary to provide a basic overview supporting future research.

The different professional and conceptual directions relate to the field of morphology within their own interpretive framework. Only a few summary-type analyses focus mainly on foreign research; however, it is also essential to understand Hungary's national research theories, methods, and fields. This article aims not simply to describe urban morphological research and its directions but to find common ground and compile an overview system.
The article presents the main trends and methods of analysis and their representatives - without claiming to be exhaustive - of urban morphological research through the initial, classical or traditional urban geographical and architectural approach and the modern or contemporary statistical and data analytical approach. By analysing and comparing the two major "eras" and their differences, similarities, the possibilities for further development can be outlined, meaning bringing together the different disciplines or deepening the existing, separate research fields.

\section{The theoretical background of morphology and urban morphology}

\subsection{The general interpretation of morphology}

It is necessary to formulate the meaning of morphology and urban morphology as the basic concept of the present writing. The definition of morphology initially spread in biology and linguistics in the middle of the $19^{\text {th }}$ century; today, it is incorporated into research methods by many disciplines. The word of Greek origin means the study of shapes, the description of the formal requirements of the various theoretical sciences, the study of their system theory and function. Its use is typical in linguistics, biology 
and botany, geography, and architecture, albeit with different meanings. In linguistics, morphology represents the rules of the formation of words, while in biology and botany, it covers the shape and the structure of certain living organisms. The geographical approach of morphology describes the Earth's surface, dealing with the formation and transformation of these structures and the regularities of their development (Kislexikon.hu, 2021).

The socio-geographical sciences distinguish two types of urban morphological studies:

1. classical morphology that analyses the formal and structural features of the settlement, and

2. functional morphology, which examines the relationship between the explored features and the function associated with them, as well as their structural transformations (Tóth, 2014).

Architecture interprets morphology as the study of urban forms by which we try to give a meaning and framework to the built environment around us. Urban morphological research aims to understand settlements, from examining the urban plots as basic "cells" through the building stock, street network, and land use to analysing the urban structure and the city body. These studies thus examine the functional and cultural content related to the individual formal features, the characteristics of the settlement's structure, and the regularities formed over time. With the help of this research, the processes that define the settlements can be explored. It is then possible to determine what interventions can be carried out without damaging the cultural traditions and built heritage and envisage development efforts to improve the perceived problems (Barke, 2018; Kissfazekas and Gurdon, 2014).

As settlements are the physical projections of the past and present lifestyles of the people living in them, which changes structurally over time, their complete morphological study requires a comprehensive knowledge. Therefore, the morphological analysis of the built environment cannot be classified as a research area of a single field of science, as it requires close cooperation within architecture, geography, landscape architecture, ethnography and history, even though these disciplines analyse settlements from a different approach (Barke, 2018; Kissfazekas and Gurdon, 2014).

The historical analysis of settlements has gained new momentum since the end of the previous century. On a broader scale, new, mainly quantitative research and methods support the exploration and analysis of urban morphological regularities and facilitate the successful implementation and integration of ongoing urban planning projects. The significance of urban morphology is thus now indisputable not only in theoretical application but also in practice.

\subsection{The forerunners of urban morphology}

The incipience of urban morphological research dates back to the end of the $19^{\text {th }}$ and the beginning of the $20^{\text {th }}$ centuries. One of its first representatives was the sociologist D. Émile Durkheim, who studied the social aspects of spatiality. In addition to the general demographic studies, Durkheim innovatively analysed the material and spatial components created by human activity (forms of housing, geographical formations). His morphological studies were no longer only exploratory and descriptive but also concerned the study of causal relationships and their impact assessment (Berger, 2019).

The origin of urban morphology can also be traced back to the work of the German urban and human geographers such as F. Ratzel, W. Geisler, J. Fritz, O. Schlüter, H. Bobek, H. Hassinger and H. Louis. Initially, human geographers tried to understand why towns were created and why on a particular location; later, they started to focus on the examination of the layouts of urban areas and their functional structure. They also researched the historical town plans to explore the original composition of towns. They mainly dealt with the historical development and geographical analysis of the European city forms and their visual appearance, such as the description of street layout, transportation routes, building types, building forms, and building materials. Their new, coloured maps also majorly impacted later urban morphology researchers (Csapó, 2016; Hofmeister, 2004).

Although the theories and work of the sociologists at the Chicago School regarding the early functional studies of settlements cannot be considered as actual urban morphological analysis, their model schemes have inspired several researchers, even urban morphologists. The Chicago School tried to answer how particular functions and social groups are located in urban space by depicting a scheme of urban structures whilst disregarding the specific, real built environment. First, R. E. Park and E. Burgess created the concentric zone model in 1926, which illustrated the correlations by separating seven urban zones. In 1939, H. Hoyt created the radiating sector model, in which each function is located, and it expands along different sectors, strung on the axes of major transport routes. The third model, the multiple nuclei theory can be linked to the 
names of C. Harris and E. Ullmann. According to them, many cities are not organised around a single centre but are merging previously independent city nuclei defined by different natural and artificial factors (Pirisi et al., 2015).

\section{The systematisation of urban morphological research}

Thanks to the early representatives of urban morphology, the continuous development of geography, and the changes in architectural and societal trends, an increasing number of experts representing several disciplines, began to deal with settlements' historical and structural research. The systematisation and summary analysis of the different scientific trends, both foreign and Hungarian research dealing with urban morphology, can be separated according to each research endeavour's approach, methods, and tools, as shown in Fig. 1. This article aims to examine the directions in urban morphology from these three main aspects while presenting the historical development process necessary for understanding the present situation by classical and modern morphological research directives.

The systematisation can help review the different methodologies and their possible combinations, thus formulating and giving a basis to the most appropriate, possibly original, method for the author's future research.

\subsection{Three possible classification aspects of urban morphological research}

\subsubsection{Approaches}

Three European schools, Italian, English and French, established after World War II, can be linked to early classical urban morphology research. Their representatives developed new theories and methodologies during the structural and functional study of settlements, which still serve as a starting point for urban morphology specialists. The scientific theoretical background of these three schools represents three morphological investigation directions with different approaches, considering the aim

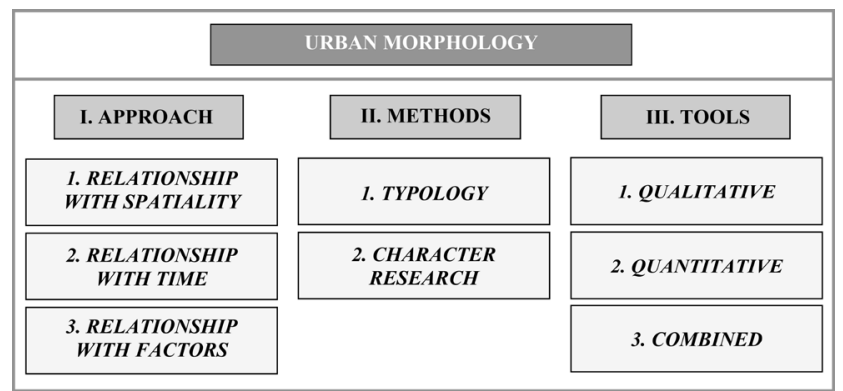

Fig. 1 The three main classifications of urban morphological studies (Source: author's editing) of the research. However, in the case of early urban morphological research, the complex approach was not necessarily present, nor was the exchange of information and communication between disciplines.

The representatives of the Italian school, who mainly were practising designers, sought to create an architecture - contrary to the modernist spirit - that could also take the historical traditions into account. Their principles primarily reflected an architectural approach concentrating on a particular era and focusing on spatiality by determining the shapes and elements of urban spaces.

The researchers of the English school tried to understand the elements and characteristics of the urban form and its changes over time. This included the process and factors of its development, analysing why and how the settlements were established. Their mainly geographical approach researched the regularities, usage, and network connections within urban areas and elements.

The aim of the representatives of the French school was to explore the design principles of each architectural era and to study their effect on the form and image of the cities. The school applied both the architectural and sociological approaches by considering the spatial representations of different social features (Moudon, 1997).

Fig. 2 shows the individual analytical topics connected to urban morphology that emerged. On the one hand, they can be separated but, especially nowadays, can also be used and applied in combination.

The founding of the Italian school is related to Saverio Muratori, an architect, who opposing modernist principles, sought a basis for his design work with morphological research. He was strongly criticised by the modern

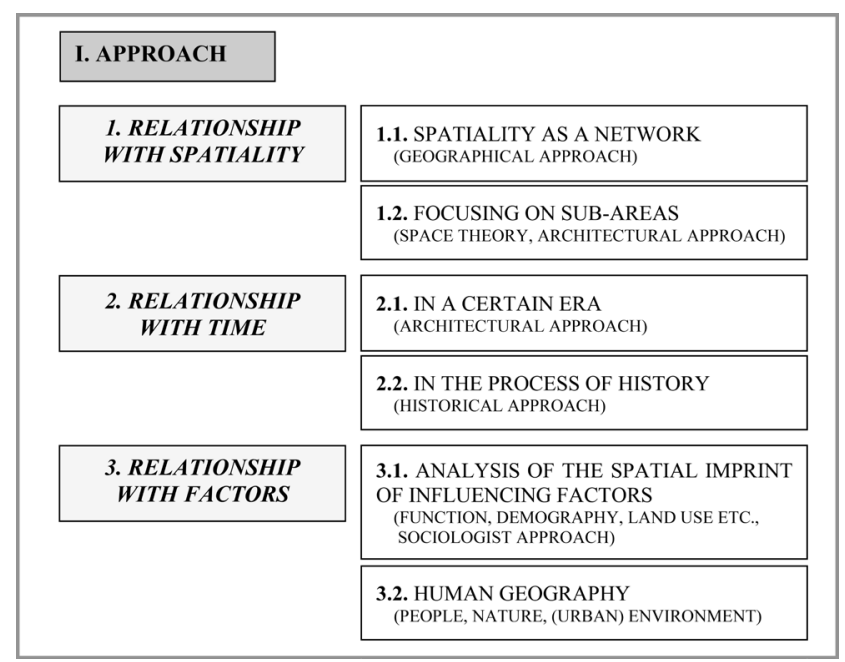

Fig. 2 The systematisation of urban morphological studies from the perspective of approach principles (Source: author's editing) 
architectural society of that time. Muratori carried out historical, spatial and typo-morphological studies, mainly on the example of Venice and Rome. In his theory of "Operational history", in which he described settlements as living, ever-changing organisms, he also dealt with the urbanisation activities of the planners and the locals. In his urban typo-morphology, he was interested in the form of urban spaces and the elements that determine their arrangements (Fig. 2 points 1.2., 2.1., 2.2.). He also analysed, among others, the built heritage of the centre of Venice (Cataldi et al., 2002; Chiaradia, 2019; Moudon, 1997).

Gianfranco Caniggia, as another defining figure of the Italian school, continued Muratori's theoretical ideas and practical principles. He aimed to simplify and make the theory - which he called procedural typology - more understandable by highlighting the building types as basic units of urban form. He also dealt with the relations of the individual formal elements (building fabric, the shape of plots, streets, and squares) to provide the most thorough characterisation for his typology (Fig. 2 points 1.2., 2.1.). Muratori's legacy has served as a model for several Italian researchers, such as C. Aymonino, G. Cataldi, G. L. Maffei, G. Strappa, E. Lavagnino and P. Vaccaro. Aldo Rossi's well-known analysis of the "traditional" type of building and his writings on the significance of historic settlements (Fig. 2 points 1.2., 2.1.) were also - albeit not admittedly inspired by Muratori. (Cataldi et al., 2002; Chiaradia, 2019; Kissfazekas and Gurdon, 2014; Moudon, 1997).

The English school was established by the geographer M. G. R. Conzen almost at the same time as the Italian school. The early German urban geography researchers had a significant influence on Conzen's work. In his study of Alnwick (1960), he developed an analytical method by giving a new reading to urban morphological studies. He identified three main areas of analysis concerning the urban form: the town plan, the building fabric - as patterns and spatial structure of the built forms -, and land use including social and economic impacts - and its changes over time (Fig. 2 points 1.1., 2.2., 3.1.). He divided the town plan into three other key elements: plots, streets and buildings, whose interaction gives the unique character of the given settlement (Conzen, 1960; Whitehand, 2001).

Conzen, continuing his mentor Herbert Louis's work, studied non-traditional urban plots, fringe belts. These fringe belts form a dividing zone between residential areas with different historical traditions and morphological features. With the help of these, he isolated morphological regions, which form uniform spatial patterns, thus separating themselves from their surroundings, conforming to the different economic, physical and social environments generated by history (Erin et al., 2017; Whitehand, 2001).

In his research on urban morphology, Conzen was criticised for favouring the experimental and direct perception studies, which opposed the quantitative and non-qualitative methods emerging in urban geography after the war. Nevertheless, his theories and analytical methods found more followers, such as J. W. R. Whitehand, P. Larkham, N. Morton, K. Kropf or K. Lilley (Erin et al., 2017; Whitehand, 2001).

Whitehand, who was also a geographer, based on the theories of Conzen, studied micromorphological phenomena (plot analysis, neighbourhood impacts). He examined the relationships between morphological periods and different typological processes (linking Conzen's theory and Caniggia's typological analysis) and the relationship between decision-making and urban form (transformation or possible recycling of fringe belts). His historical-geographical approach of urban morphology has been extended to the east (China, Japan, Korea) in recent years. He has researched the connections and differences of international urban morphology and the possibilities of preserving the historical and urban landscape heritage (University of Birmingham, 2020; Whitehand, 2001).

The third school was founded by architects (Jean Castex, Philippe Panerai) and sociologists (Jean-Charles DePaule) in France in the late 1960s, where researchers, similarly to the Italian school, formulated a critique of modernist architectural principles that ignored historical traditions. In their theoretical and practical work, its representatives presented and applied the theses and methodological elements formulated by the Italian Muratori, whose work was unknown in France at that time (Moudon, 1997).

The researchers of the French school mainly studied the spatial relations between the urban form elements, their qualification and quantification. They examined relationships within the plot, the built-in ratio, the urban block, and the geometrical and topological relations of the urban fabric (Fig. 2 point 1.2.). In addition, several individual and detailed studies were carried out. Their studies have now been extended to the Eastern and Arab worlds (Panerai, 2018) ${ }^{1}$. The disappointment in the principles of

1 Philippe Panerai mainly deals with the analysis and typology of the forms, spatial elements and fabric of the cities. He extends his studies to the Eastern world as well to the Arab East, China and Japan (Panerai, 2018). 
modernism also raised the theme of urban life and liveability (Fig. 2 point 3.1.), which aroused the interest of sociologists and art historians such as Henri Lefebvre or Francoise Boudon and André Chastel (Erin et al., 2017; Moudon, 1997).

Interestingly, the American historian and sociologist Lewis Mumford also rejected the architectural principles of modern cities. Referring to their adverse effects (dispersal, alienation, technical dependence), he identified the medieval, organic cities as well as the Greek polis (Fig. 2 point 3.1.) as realisations of ideal social and economic units (Casillo, 1992).

The researchers of the earlier mentioned three schools endeavoured to develop fundamental theses on urban morphology for better transparency and international connectivity. Two common scopes have been formulated:

1. we can analyse and understand a city through its physical form and its medium;

2. three basic elements of morphological research can be distinguished, the shape - building, plot, street -, the resolution of the layers and the historicity, namely the time, and the changes over time (Moudon, 1997).

In the first half of the $20^{\text {th }}$ century, the number of foreign urban morphology researchers grew steadily; however, in Hungary, morphology was only a topic of interest for a narrow circle of researchers.

The beginning of urban morphological research in Hungary can be traced back to the early 1900s. Until World War II, it was one of the most important research subjects in urban geography. The most significant influence on Hungarian researchers was exerted by the early works of the representatives of German urban geography. Gyula Prinz and Károly Kogutowicz were the first geographers who dealt with topics related to settlements. They examined the history, morphology, formation and changes of towns and the relationship between local and situational energies. Using a German example, they also covered the study of house types and installation methods (Csapó, 2016).

In Hungary, similarly to the representatives of the English school, the geographical approach was typical, of which the most prominent representative was the geographer Tibor Mendöl. The main subject of his scientific activity was, among other things, the study of the Hungarian Alföld's (Great Plain) settlements, which have a "typically Hungarian" - derived from the traditions of peasant and farm society - special urban form; it later aroused the interest of other researchers. Mendöl separated the founded and grown cities and their different images and structural appearances and dealt with human geography (Fig. 2 points 1.1., 2.2., 3.2.), the interactions within nature, landscape and society (Csapó, 2016; Mendöl, 1932).

In the absence of statistical data, in his research Mendöl attached a unique role to the empirical analyses and the representation of his investigations on self-made maps. In addition to the morphological elements, the maps also depicted the location and boundary of the towns' centres. This provided a well-understandable and groupable, new reading to the urban form and shape studies. With the help of these studies, Mendöl created a methodological background of the Hungarian functional analyses, where he related the division of labour of the population, the spatial location of the social classes and in addition, the morphological image (Fig. 2 point 3.1.). His theory about functional morphology divided settlements into concentric zones, similar to the previously mentioned researchers' works at the Chicago School. According to his findings, the narrower the examined area and the smaller the settlement is, the fewer zones can be separated in the given unit, and the stronger the connection between the composition of the present society and the formal appearance (Becsei, 2016; Csapó, 2016). The name of Tibor Mendöl is now associated with the Hungarian morphological research. His activities later provided a methodological basis not only for urban geography but also for architectural research.

After World Word II, urban geographical research, including morphological analyses, was pushed into the background in Hungary due to the planned urban developments and the creation of new, functionality-focused cities and districts that ignored historicity. The research topic of urban geography became the confrontation between the new socialist urban planning principles and the existing urban fabric, and the search of the role of urban science in the city development. Most of the investigations were focused on cities, such as Mihály Sümeghy's study on the internal functional categorisation of Hungarian middle towns, Edit Lettrich's works on the functional zones of the cities in Alföld (Great Plain), or József Becsei's urban structure research in Békés county (Csapó, 2016).

Only a few people have studied the Hungarian villages, including Jenő Major, a geographer who has published several urban science and morphology articles. He examined the structural and operational problems of the villages during the socialist era, determined the purpose and content elements of the village investigations, and performed the historical, geographical and morphological analysis of 
several small villages. He dealt with the exploration of the past and the present of the settlements and the definition of their future requirements. Through his scientific research, he tried to provide a guidance and a design directive for the participants of village construction and village development (Major and Valló, 1954a; 1954b).

During the scientific study of the villages, Major explored, among other things, the geographical position and conditions, the history, the agricultural and structural features, the plot, square and street network, the main buildings and the characteristic elements of the given settlement, as well as the image of the village, its integration into the landscape and adaptation to natural conditions. In some of his research, he used data from archaeological excavations, ethnographic studies, medieval diploma materials and boundary descriptions to reconstruct the early settlement nuclei (Laboda and Major, 1956; Major, 1959).

The theoretical and methodological structure of his studies is exemplary. He is one of the few researchers on the subject who has worked with a kind of integrated, interdisciplinary approach combining the geographical, architectural and societal perspectives covering almost all directives presented in Fig. 2.

After the change of regime in 1989, urban structure research played an important role among geographers again. The main areas of the investigations were the analysis of the causes of the alteration of functional zones and morphological elements of large cities and the capital, the mapping and rehabilitation of degraded and segregated neighbourhoods. Currently, Tamás Csapó conducts urban morphological research mainly related to large cities (Csapó, 2016).

Hungarian architects began to deal with the analysis of buildings and towns a little later, in the second half of the $20^{\text {th }}$ century, focusing mainly on spatial theory research (Fig. 2 points 1.2., 3.1.). Although the investigations were of a high standard, only a few were represented. It is worth mentioning Zoltán Szentkirályi's historical, spatial and street artistic investigations, Pál Granasztói's research on the connections between social and cultural differences and the image of the towns. Frigyes Pogány's work on protection of monuments and town aesthetics, and also the spatial quality analyses of J. Gyula Hajnóczi (Hajnóczi, 1991; Kiss, 2011; Kissfazekas and Gurdon, 2014).

Recently, Tamás Meggyesi, István Schneller and Melinda Benkő have dealt with urban and architectural space theory, Kornélia Kissfazekas mainly researches the morphological characteristics and urban forms of state socialism, while Éva Lovra studies the Habsburg Empire (Fig. 2 point 2.1.). The architectural analysis of urban morphology in Hungary thus still hides many possibilities.

\subsubsection{Research methods}

If we examine the early urban morphological studies from the point of view of each investigation methodology, it can be said that two types of research method were typical, as shown in Fig. 3:

1. the typology, which dealt with the exploration and systematisation of individual architectural products, and also with the relationship between these elements and the historic urban structure,

2. and the character research, which examined the characteristics of each typology in different eras, incorporating the fact of temporality (Kissfazekas and Gurdon, 2014).

\section{Typology}

Contrary to the modernist architectural principles, the representatives of the Italian and French schools explored the urban and formal elements of the settlements mainly through their typological studies, emphasising respecting historical traditions (Fig. 3 point 1.2.). Their investigations treated the historical dimension and the specific historical eras as a spatial representation of a given society in the complex urban planning system. The research principles and methodology they represented also served as a role model for several future experts.

Among others, Christopher Alexander conducted typological research that could be considered as morphology. He created the specific language of the urban elements so-called patterns - and thus the readability of the settlements (Alexander et al., 1977). The typological research of Rob Krier (1979) and Leon Krier (1998) claimed the dynamic richness of the medieval urban forms and

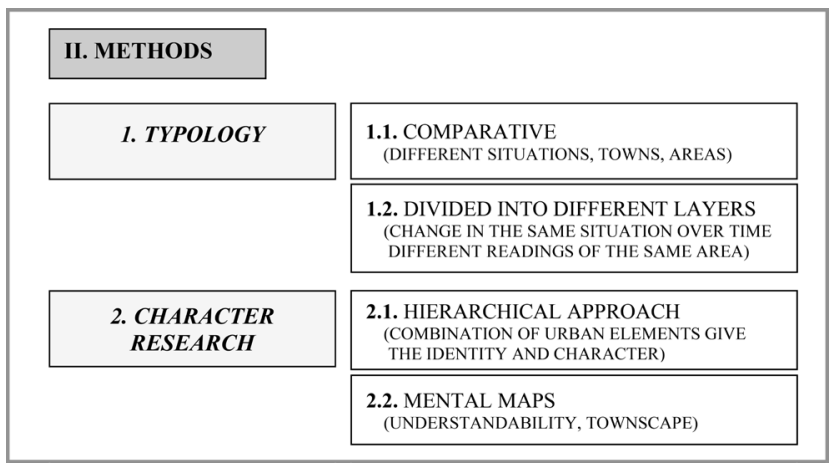

Fig. 3 The systematisation of urban morphological studies from the research methods perspective (Source: author's editing) 
buildings as the opposite of the townscapes transformed by the "indifference" of modernism (Fig. 3 point 1.1.). The research of the Krier brothers draws attention to the specific and unique formal representations of European culture. Their typologies about squares and streets made with analytical drawing techniques highlight the need to return to urban space and urban culture and traditions during the planning process (Ekler, 1981).

The early Hungarian urban morphology researchers also dealt mainly with typology by comparing and categorising settlements of different types and sizes, revealing their functional division and structure, and temporal development processes (Fig. 3 points 1.1., 1.2.). The analysis of different building types has also started.

One of the most defining figures of Hungarian urban morphology research is the architect and urban planner Tamás Meggyesi. He sees morphology and the urban fabric as a living organism with personality, character and spirituality. He aimed to bring back the spatial organising role of the street in contrast to the theory of modernism and paid particular attention to the phenomenon of space as a meeting place for social encounters and thus of the scene of life.

Meggyesi dealt with the study and understanding of settlement types and the Hungarian settlement cultures. His morphological research mainly focused on the streets and squares of the towns in the Alföld (Great Plain), where he explored their characteristics and unique environmental patterns. He created the genetic typology of the residential house that describes the metamorphosis of buildings as an organic and continuous development depending on time and cultural traditions. His studies were mainly typological and aesthetic (Fig. 3 points 1.1., 1.2.). He wove his individual and personal impressions, observations into his research on urban morphology (Meggyesi, 2008).

\section{Character research}

The members of the English school also dealt with typology by separating the individual elements and layers of settlement form and their changes over time; however, they have already examined the relationship and nature of each layer too, providing a basis for character research.

Among the representatives of character research, Gordon Cullen, Kevin Lynch, and Karl Kropf are worth mentioning. Karl Kropf developed the combination of the analytical method of Conzen and Caniggia in his research on urban fabric and town character. He identified seven components - material, structures, rooms or spaces, buildings, plots, streets and blocks and the urban tissue - that build the city in a hierarchical order based on a sub-whole relationship, defining its character and unique identity by combining each element (Fig. 3 point 2.1.). Kropf also dealt with the parallelism of urban morphology and morphology defined in linguistics and biology. He determined that the research area of urban morphology is too broad and difficult to follow, so he suggested dividing it into well-interpreted and separable parts (Kropf, 1996; Kropf and Malfroy, 2013).

Gordon Cullen developed a new analytical method for the visual research of settlements (Fig. 3 point 2.2.). His drawings about the townscape, his writings on the role of perception, and his research about the connection of open spaces and social groups that shape and use them were very inspiring for later researchers (Cullen, 1966; Sordi, 2016). Kevin Lynch's work about the image of the cities has also gained widespread notoriety. Through his research and the depiction of mental maps (Fig. 3 point 2.2.), Lynch sought the answer to the question of what the shapes and elements of a town mean to the people who live there and how designers could help make cities more understandable and vibrant (Lynch, 1960).

Only a few Hungarian researchers paid attention to character research, typology was more common as it is today. At the same time, architects dealing mainly with space theory (Szentkirályi, Granasztói, Pogány) were also interested in urban aesthetics, the image defined by the town's cultural and societal traditions and the elements to be preserved. Meggyesi, in addition to his typological studies, introduced the importance of roads and their visual analyses through promenadology (Fig. 3 point 2.2.), the science of walking (Meggyesi, 2013). Along with the comparative studies of the settlements, T. Mendöl also examined the image and appearance of the towns, and like J. Major, tried to explore the elements that make them unique and give them their identity (Fig. 3 points 1.2., 2.1.).

\subsubsection{Tools}

While the approaches, the methods and the principles of urban morphological studies remained almost unchanged, its toolkit started to undergo many changes through time. This shift is currently taking place at an exponential rate by overshadowing pre-technical values. Fig. 4 presents the differentiation of the techniques that are available for the past and present researchers.

The classical or traditional morphological research was mainly qualitative, with hand-made, coloured maps, diagrams and - as an early quantitative approach - with 


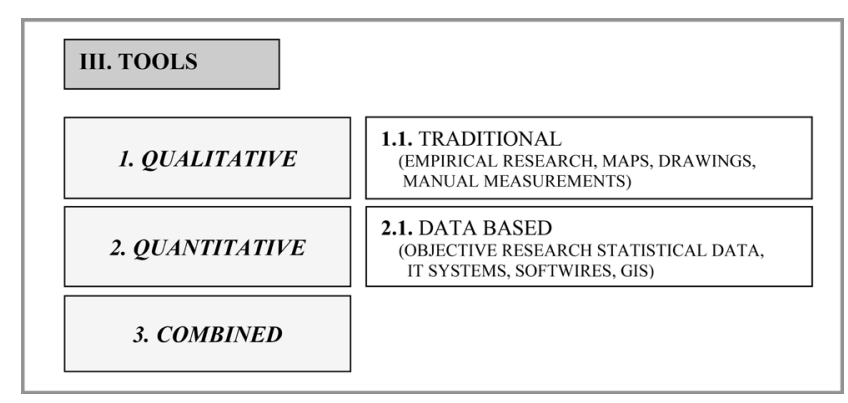

Fig. 4 The systematisation of urban morphological studies from its toolkit point of view (Source: author's editing)

manual measurements and calculations (Fig. 4 point 1.1.). In addition to the empirical research, their studies mainly were made using the content elements of historical maps and documents, archaeological investigations, ethnographic research descriptions and archival documents. In the studies of traditional morphology researchers, a close relationship, which is also rich in emotional attachment and subjectivity with a given examined settlement, area or morphological element, is perceptible.

In the second half of the $20^{\text {th }}$ century, with the development of technology and the emergence of new phenomena and problems affecting the whole world (e.g. sustainability, motorisation, pollution), many new "modern" urban morphological research techniques were created. The primarily qualitative examinations of the previously presented researchers, which focused on experience, direct perception and visuality in a specific place or formal element, were gradually supplemented or replaced by quantitative, statistically-based measurements (Fig. 4 point 2.1).

The emergence of quantitative approaches in urban morphology can be dated back to the 1960s, when the various measurements, calculations and evaluations of the spatial analysis of cities were still being done manually. In the 1970s, the first computer mathematical models were introduced to explore the morphological characteristics of the built environment, as well as graph theory, which made it possible to measure and compare different spatial and geographical patterns, urban tissues and buildings by two components, nodes and edges (Erin et al., 2017; Ostwald, 2011).

With the development of computer technology, the Geographic Information Systems (GIS) and the availability of statistical data, the scale of the subject of urban morphology has changed. In addition to examining individual urban elements and characteristics and the monographic description of settlements, researchers have been able to think on a more significant - metropolitan, agglomeration, urban area and urban relation - level. At the same time, the micro-level, the human scale study of urban tissue has also remained important.

Two directions became separable within the quantitative approach of urban morphology:

1. the configurational analysis, which focuses on the structure of cities as networks, examining its patterns, movements and connections, and

2. the spatial analysis, which uses GIS tools to examine the urban fabric and its multilayering, and the specific spatial position of the elements (Erin et al., 2017).

One of the best-known configurational analyses is space syntax. The essence of the method presented by Hillier and Hanson in 1984, is the analysis of the relationship between the physical space and society by the characteristics of a given spatial situation. Those public areas of the urban network that allow human movement and its observation can be the subject of the study (Fig. 2 points 1.1., 3.1.). Space syntax usually determines the configuration of road networks at two different levels - global and local by calculating the results revealed by three distance measurement modes: the fewest turns paths, least angle change paths, and shortest physical paths. The method can be used to explore not only a homogeneous road network, but also its important nodes, centres and sub-centres, accessibility and permeability, and the density points generated by the functions present on each section (Hillier, 2007; Kiss, 2011; Xu et al., 2020).

Nowadays, space syntax is often used in conjunction with various GIS systems, resulting in a broader field of analysis. In urban planning, besides the morphological research, space syntax also deals with topics such as transport modelling, the examination of the accessibility of historic districts or even brownfields, the effects and possible directions of urban renewal and social urban regeneration initiatives, and also the permeability and liveability of urban structure. It analyses the movements and interests of tourists arriving in the city, the locations and contexts of peripheral and degraded areas and urban crime from a spatial perspective.

The technological developments and the Geographical Information System (GIS) have made it possible to carry out spatial analyses that can no longer reveal only the qualitative characteristics of individual spatial systems, urban tissues and forms. However, they can also combine quantitative data to make socio-economic and spatial correlations measurable and analysable (Moudon, 1997). 
By relying on the theoretical and methodological background of classical morphological studies with GIS systems, a number of research studies have been conducted, revealing certain layers of towns and their geographical environment, land use, and historical changes.

Nowadays, the work of urban morphology researchers is supported by many information technology systems and software in addition to GIS. CAD systems (Computer-aided design) have enabled 2D vector and 3D spatial modelling. Various software that can calculate statistics, draw graphs or 3D elements, heatmaps, as well as new programming languages and program systems have emerged, which have generated new perspectives, usually without direct perception or subjectivity (numerical analyses, matrix calculations, street space diagrams, skyline studies). With the help of the different LANDSAT recordings, we can examine the built-in and non-built-in parts of each area, or even those with different vegetation and their subsequent transformation. Some web mapping services, such as Google Maps or Google Earth, have allowed insights into almost every corner of the Earth over the past 20-25 years via satellite imagery, providing an opportunity to explore and analyse even the rapid changes that have taken place over time (Oliveira et al., 2014).

By examining the current trends, it can be stated that the traditional analytical methods are still in use today and provide a basis for contemporary researchers. The two great "eras", the traditional and the contemporary, live together in the present, and they are constantly evolving, deepening or supplementing. Three directions can be observed regarding the relationship between the toolkit of the morphological studies of the two "eras" (Fig. 4 point 3):

- Almost complete adoption of classical methods, but with the support of manual measurements and the visualisation of maps with information technology tools (GIS, CAD, drawing and 3D programs). In this case, the qualitative approach is still strongly represented.

- The development of new research technics and principles in addition to classical ones, which represent a quantitative approach based on mainly statistical and objective data as well as computer software (space syntax, numerical analyses). In this case, subjectivity can be almost entirely excluded, and only pure numerical facts give the results.

- A combined application of new research trends and classical studies, in which both qualitative and quantitative analyses contribute to the value of the scientific work.

\subsection{New directions}

At the beginning of morphological research, the exchange of information and the influence between the different disciplines involved was low, and still incomplete even today. However, the different research principles, methods and tools presented above attract more and more disciplines. In addition to geographers, architects and sociologists, historians, archaeologists, ethnographers, and social scientists are now studying urban morphology. With the growth of interdisciplinary communication and the exchange of knowledge, new research topics and opportunities are opening up for professionals.

In recent years, several inter- and multidisciplinary research methods have emerged, presumably due to the advances in technology and thus the faster flow of information, the simplification of individual analyses and their visual representation, and actual recognition of the topic and its complexity. The inter- and multidisciplinary initiatives, among other things, together with sustainable development, urban ecology, sociology or psychology, formulate formal and spatial theses at an urban level. New research topics have appeared, such as the usage of renewable energies and their shaping impact on cities, the search for sustainable urban patterns and social elements, the causes of slums, the study of urban green spaces and biodiversity or the structural reconstruction of areas destroyed by natural disasters (Marcus et al., 2019; Oliveira et al., 2014).

The multi-scalar approach also comes to the fore, exploring hierarchical relationships, characteristics, and the different levels' tasks within each research topic, such as the spatial socio-ecological dynamics of a neighbourhood, a city, and a state. Today, we try to achieve that urban morphological research increasingly contributes to the compound urban planning process by defining the developmental regulations, directions, and possibilities of individual settlements or wider areas. Furthermore, new theories, methodologies and tools with a more complex, multidisciplinary approach still hide many opportunities in the field of the study of urban morphology.

\section{Conclusion}

The extensive urban morphological studies that inspire across disciplines have evolved over time, yet the analysis of the physical framework, shape and structure, the different historical layers and typologies that appear in them, and the examination of historical changes have become general. Today an increasing number of specialisation fields reveals a broader range of urban morphological 
research directions, which shows that the discipline has even more layers and opportunities.

However, it can be observed that research by sentimentalism, perception and the opinion formed by it is in decline as opposed to quantifiable research based purely on objectivity. Although the analysis of urban morphological elements, the direction and extent of historical and land-use changes, or the relations within and between settlements can be quantified and objectively analysed, it is essential to conduct studies based on experience. Personal impressions can supplement this since towns are not only

\section{References}

Alexander, C., Ishikawa, S., Silverstein, M., Jacobson, M., FiksdahlKing, I., Angel, S. (1977) "A pattern Language: Towns, Buildings, Construction", Oxford University Press, New York, NY, USA.

Barke, M. (2018) "The Importance of Urban Form as an Object of Study", In: Oliveira, V. (ed.) Teaching Urban Morphology, Springer, Cham, Switzerland, pp. 11-30. https://doi.org/10.1007/978-3-319-76126-8_2

Becsei, J. (2016) "Mendöl Tibor geográfiája" (Geography of Tibor Mendöl), Településföldrajzi Tanulmányok, 5(1), pp. 3-16. [online] Available at: http://ojs.elte.hu/index.php/tft/article/ download/133/111/ [Accessed: 29 January 2021] (in Hungarian)

Berger, V. (2019) "Morfológia és osztályozás: Durkheim és a Durkheimiskola hozzájárulása a szociológiai térelméletekhez" (Morphology and classification: The contribution of Durkheim and the Durkheim school to the sociological theories of space), Társadalomtudományi szemle, 9(2), pp. 1-14. (in Hungarian)

https://doi.org/10.18030/socio.hu.2019.2.1

Casillo, R. (1992) "Lewis Mumford and the Organist Concept in Social Thought", Journal of the History of Ideas, 53(1), pp. 91-116. https://doi.org/10.2307/2709912

Cataldi, G., Maffei G. L., Vaccaro, P. (2002) "Saverio Muratori and the Italian school of planning typology", Urban Morphology, 6(1), pp. 3-14. [online] Available at: http://www.urbanform.org/pdf/ catal2002.pdf [Accessed: 28 January 2021]

Chiaradia, A. J. F. (2019) "Urban Morphology/Urban Form", In: Orum, A. (ed.) The Wiley Blackwell Encyclopedia of Urban and Regional Studies, New York, USA, pp. 1-6. https://doi.org/10.1002/9781118568446.eurs0382

Conzen, M. R. G. (1960) "Alnwick, Northumberland: A Study in TownPlan Analysis", Transactions and Papers (Institute of British Geographers), 1960(27), pp. iii-122. https://doi.org/10.2307/621094

Cullen, G. (1966) "The Concise Townscape", University Press, Cambridge, UK.

Csapó, T. (2016) "Település-morfológiai kutatások Mendöl Tibor óta napjainkig" (Settlement morphology researches since Tibor Mendöl to date), Településföldrajzi Tanulmányok, 5(1), pp. 17-26. [online] Available at: http://ojs.elte.hu/index.php/tft/article/ view/134 [Accessed: 28 January 2021] (in Hungarian) artificial, static environments, but also the cultural representations and spatially appearing memories of a given society of a given age. In a word, we need to keep in mind that a scientific judgment can never be based merely on complete objectivity.

Urban morphology is currently undergoing a paradigm shift. In addition to the qualitative and quantitative analysis of the general research topics and approaches presented in this article, the aim is to examine and deepen the usefulness and practical applicability of this constantly evolving discipline.

Ekler, D. (ed.) (1981) "Látóhatár: Városok emlékezete (A "Bercsényi 28-30" melléklete 1980. 1.)" (Horizon: Memories of cities (Appendix of "Bercsényi 28-30" 1980. 1.), [pdf] Korunk, 40(4), pp. 331-333. Available at: https://epa.oszk.hu/00400/00458/00518/pdf/EPA00458_ Korunk_1981_04_326-336.pdf [Accessed: 29 January 2021] (in Hungarian)

Erin, I., Araldi, A., Fusco, G., Cubukcu, E. (2017) "Quantitative Methods of Urban Morphology in Urban Environmental Psychology", In: 24th ISUF - City and Territory in the Globalization Age International Conference, Valencia, Spain, pp. 1391-1400. https://doi.org/10.4995/ISUF2017.2017.5732

Hajnóczi, J. Gy. (1991) "Vallum és intervallum: Az építészeti tér analitikus elmélete" (Vallum and Interval: An Analytical Theory of Architectural Space), Akadémiai Kiadó, Budapest, Hungary. (in Hungarian)

Hillier, B. (2007) "Space is the machine: A configurational theory of architecture", Space Syntax, London, UK. [online] Available at: https://discovery.ucl.ac.uk/id/eprint/3881/ [Accessed: 29 January 2021]

Hofmeister, B. (2004) "The study of urban form in Germany", Urban Morphology, 8(1), pp. 3-12. [online] Available at: http://www. urbanform.org/pdf/hofmeister2004.pdf [Accessed: 29 January 2021]

Kiss, Gy. (2011) "Településépítészet" (Urban architecture), Szent István Egyetem, Budapest, Hungary. [online] Available at: https://docplayer.hu/3963347-Telepulesepiteszet-kiss-gyula.html [Accessed: 29 January 2021] (in Hungarian)

Kissfazekas, K., Gurdon, B. (2014) "A várostest morfológiája" (Urban corpus morphology), Építés - Építészettudomány, 42(3-4), pp. 173-205. (in Hungarian)

https://doi.org/10.1556/eptud.42.2014.3-4.5

Krier, L. (1998) "Architecture: Choice or fate", Papadakis Publisher, Windsor, UK.

Krier, R. (1979) "Urban Space", Academy Editions, London, UK. [online] Available at: http://www.sze.hu/ nemethi/V\%C1ROS\%20 szakirodalom/rob\%20krier\%20-\%20urban\%20 space.pdf [Accessed: 29 January 2021]

Kropf, K. (1996) "Urban tissue and the character of towns", Urban Design International, 1(3), pp. 247-263.

https://doi.org/10.1057/udi.1996.32 
Kropf, K., Malfroy, S. (2013) "What is urban morphology supposed to be about? Specialization and the growth of a discipline", Urban Morphology, 17(2), pp. 128-131.

Kislexikon.hu (2021) "Morfológia" (Morphology), [online] Available at: http://www.kislexikon.hu/index.php?f=morfol\%F3gia\&all=1 [Accessed: 28 January 2021] (in Hungarian)

Laboda, Zs., Major, J. (1956) "Egy Duna menti falu településtudományi vizsgálata" (The settlement science study of a village along the Danube), Településtudományi közlemények, 5(8), pp. 55-74. (in Hungarian)

Lynch, K. (1960) "The image of the city", [pdf] The MIT Press, Cambridge, MA, USA. Available at: https://www.miguelangelmartinez.net/ IMG/pdf/1960_Kevin_Lynch_The_Image_of_The_City_book.pdf [Accessed: 29 January 2021]

Major, J., Valló, I. (1954a) "A településtudomány feladatai a faluépítésben" (The tasks of urban science in village construction), Településtudományi közlemények, 3(6), pp. 5-12. (in Hungarian)

Major, J., Valló, I. (1954b) "A faluvizsgálatok célja és tartalma" (The purpose and content of village inspections), Településtudományi közlemények, 3(6), pp. 13-15. (in Hungarian)

Major, J. (1959) "Szempontok a faluépítési hagyományok kutatásának módszeréhez" (Aspects for the method of researching village building traditions), Településtudományi közlemények, 8(11), pp. 3-16. (in Hungarian)

Marcus, L. H., Pont, M. B., Barthel, S. (2019) "Towards a socioecological spatial morphology: integrating elements of urban morphology and landscape ecology", Urban Morphology, 23(2), pp. 115-139. [online] Available at: https://www.researchgate.net/ publication/336104628_Towards_a_socio-ecological_spatial_ morphology_integrating_elements_of_urban_morphology_and_ landscape_ecology [Accessed: 28 January 2021]

Meggyesi, T. (2008) "Települési kultúráink" (Our settlement cultures) Terc, Budapest, Hungary. (in Hungarian)

Meggyesi, T. (2013) "Promenadológia. Fejezetek a séta és a lineáris látványelemzés elméletéhez" (Promenadology. Chapters to the theory of linear sight analysis), Építés - Építészettudomány, 41(1-2), pp. 145-189. (in Hungarian)

https://doi.org/10.1556/eptud.41.2013.1-2.6

Mendöl, T. (1932) "Táj és ember: Az emberföldrajz áttekintése" (Landscape and man: An overview of human geography), Magyar Szemle Társaság, Budapest, Hungary. [online] Available at: http://real-eod.mtak.hu/7766/6/MTA_Konyvek_113303.pdf [Accessed: 29 January 2021] (in Hungarian)
Moudon, A. V. (1997) "Urban morphology as an emerging interdisciplinary field", Urban Morphology, 1, pp. 3-10. [online] Available at: http://www.urbanform.org/pdf/moudon1997.pdf [Accessed: 28 January 2021]

Oliveira, V., Pinho, P., Batista, L., Patatas, T., Monteiro, C. (2014) "Our common future in Urban Morphology", FEUP, Porto, Portugal.

Ostwald, M. J. (2011) "The Mathematics of Spatial Configuration: Revisiting, Revising and Critiquing Justified Plan Graph Theory", Nexus Network Journal, 13(2), pp. 445-470. [online] Available at: https://ink.springer.com/article/10.1007\%2Fs00004-011-0075-3 [Accessed: 29 January 2021]

Penerai, P. (2018) "Philippe Panerai architecte urbaniste consultant: Formes urbaines, tissus urbains" (Philippe Panerai architect urban planner consultant: Urban formes, urban fabrics) [online] Available at: https://philippe-panerai.com/villes-territoires/ [Accessed: 21 December 2020] (in French)

Pirisi, G., Trócsányi, A., Hajnal, K. (2015) "Általános társadalom- és gazdaságföldrajz" (General social and economic geography), [pdf] SZTE Elektronikus Tananyag Archívum, Szeged, Hungary, Available at: https://eta.bibl.u-szeged.hu/id/eprint/89 [Accessed: 28 January 2021] (in Hungarian)

Sordi, J. (2016) "Beyond Urbanism: The Landscape Generation", Studio Magazine of Architecture and Urbanism, 9, pp. 120-127.

Tóth, J. (ed.) (2014) "Általános társadalomföldrajz I-II" (General social geography I-II), Dialóg Campus Kiadó, Budapest, Hungary. (in Hungarian)

University of Birmingham (2020) "Professor Jeremy Whitehand", [online] Available at: https://www.birmingham.ac.uk/staff/profiles/gees/ whitehand-jeremy.aspx [Accessed: 19 December 2020]

Whitehand, J. W. R. (2001) "British urban morphology: the Conzenian tradition", Urban Morphology, 5(2), pp. 103-109. [online] Available at: http://www.urbanform.org/pdf/whitehand2001.pdf [Accessed: 28 January 2021]

Xu, Y., Rollo, J., Jones, D. S., Esteban, Y., Tong, H., Mu, Q. (2020) "Towards Sustainable Heritage Tourism: A Space Syntax-Based Analysis Method to Improve Tourists' Spatial Cognition in Chinese Historic Districts", Buildings, 10(2), Article number: 29. https://doi.org/10.3390/buildings10020029 